\title{
Aromatic Profile, Physicochemical and Sensory Traits of Dry-Fermented Sausages Produced without Nitrites Using Pork from Krškopolje Pig Reared in Organic and Conventional Husbandry
}

\author{
Martin Škrlep ${ }^{1}{ }^{1}$, Marjeta Čandek-Potokar ${ }^{1,2, *}$, Nina Batorek-Lukač ${ }^{1}$, Urška Tomažin ${ }^{1}$ and \\ Mónica Flores ${ }^{3}$ (D) \\ 1 Agricultural Institute of Slovenia, 1000 Ljubljana, Slovenia; martin.skrlep@kis.si (M.Š.); \\ nina.batorek@kis.si (N.B.-L.); urska.tomazin@kis.si (U.T.) \\ 2 Faculty of Agriculture and Life Sciences, University of Maribor, 2311 Hoče, Slovenia \\ 3 Department of Food Science, IATA-CSIC, 46980 Paterna (Valencia), Spain; mflores@iata.csic.es \\ * Correspondence: meta.candek-potokar@kis.si; Tel.: +386-1-2805124
}

Received: 29 January 2019; Accepted: 6 February 2019; Published: 12 February 2019

check for updates

Simple Summary: Consumers associate product quality more and more with the extrinsic cues related to the way animals are raised (animal welfare), agrobiodiversity, and tradition. Consumers also favor the reduced use of additives in products. To support the preservation of the autochthonous pig breeds, which are used marginally due to their lower productivity, it is important to enhance the market potential and value of their products. In light of consumer preferences for organic farming and product naturalness, the present study was designed to develop a nitrite-free product (salami type of dry-fermented sausage) from Krškopolje pigs (autochthonous Slovenian breed) and to evaluate if and how the husbandry system (organic or conventional) affects its quality. Results of this study demonstrated softer texture and somewhat less tasty dry-fermented sausages from pigs that were held in organic husbandry. This result could be ascribed to more unsaturated fat and the fact that sausages were produced without additives with antioxidant capacity.

\begin{abstract}
Dry-fermented sausages were produced in a traditional way, without addition of nitrites and starter cultures, from meat of an autochthonous breed (Krškopolje pig) raised either in a conventional indoor or organic husbandry system. Physicochemical and sensory analyses were performed at the end of processing to characterize their quality. Dry-fermented sausages from organic pork retained more moisture, which resulted in higher water activity and softer texture (instrumental and sensory). They were more oxidized (higher thiobarbituric acid reactive substances (TBARS)), in agreement with more unsaturated fatty acid profile, a higher score for rancid taste, and a higher relative abundance of volatiles from lipid $\beta$-oxidation. Overall, dry-fermented sausages from organic pork had lower levels of volatile compounds, particularly, those originating from spices (despite the same quantity added) and lower levels of amino-acid degradation. Sensory analysis showed that dry-fermented sausages from organic pork had less intensive and vivid color, tasted more bitter and sour, and had more off-tastes. The observed differences could be related to initial differences in raw material (differences in meat $\mathrm{pH}$ and level of polyunsaturated fatty acids) affecting the process of fermentation.
\end{abstract}

Keywords: pig; dry-fermented sausage; physicochemical; sensory characteristics; production system 


\section{Introduction}

Consumption of traditional food is driven by the positive attitudes of consumers for such products, associating it (among others) with naturalness [1]. The use of preservatives in meat dry-curing, particularly, the nitrites is important because of their role in typical color formation (stable cured color), characteristic cured aroma, microbiological safety, and oxidative stability, but also their interaction with numerous biochemical processes [2]. However, consumer concerns related to health risks associated with consumption of products containing nitrite and nitroso-derivatives [3] encourage meat processors to look for nitrite alternatives [4]. Processing of dry-fermented sausages is based on drying, which reduces the water activity, along with fermentation (under controlled temperature and relative humidity), during which the growth of lactic acid bacteria results in $\mathrm{pH}$ decline important for the control of spoilage bacteria and pathogens [5]. Thus, the product is stabilized for prolonged conservation. Complex physical-chemical changes occur during processing and involve major components (proteins, lipids) and additives (spices, condiments, preservation agents, microbial cultures). These changes depend on intrinsic raw material properties, microflora, and processing conditions, further affecting dehydration, microbial growth, oxidation, and which, together with the activity of meat endogenous enzymes, determine the development of final sensory characteristics $[6,7]$. Local (autochthonous) pig breeds are less performant and fattier than genetically improved pig breeds, which is the reason why many of them were abandoned. Preservation of these breeds as genetic resource can be assisted by developing products with attributes important for consumers (sensory quality, naturalness, and extrinsic cues associated with the way pigs are raised). In European Union, the autochthonous breeds are often used for the production of high-quality value-added products, in particular dry-cured pork products, as witnessed by their geographical or traditional specialty protection [8]. Krškopolje pig is the only Slovenian autochthonous pig breed, which despite growing interest remains endangered and used on small-scale, non-intensive farms, very often on ecological and agro-touristic farms [9], and their products are mainly made on the farm and marketed through direct sales. To improve the sustainability of the breed and its preservation, it is important to enhance market potential of pork products. Considering the consumer preferences for organic farming and product naturalness, the present study was designed to develop a nitrite-free product (salami type of dry-fermented sausage) from Krškopolje pigs and to evaluate if and how the husbandry system (organic or conventional) affects physiochemical properties, sensory traits, and volatile profile of dry-fermented sausages.

\section{Materials and Methods}

This work was undertaken within the normal running of the farm (respecting the Slovenian law on animal protection) and no procedures were made on pigs that would demand ethical protocols according to Directive 2010/63/EU (2010). Moreover, tissue (meat) samples were taken after the slaughter. Dry-fermented sausages (salami) for the present study were processed using the meat and fat of front legs from 24 barrows of the Krškopolje pig breed, which were raised either in a conventional indoor (12 barrows) or organic system (12 barrows), receiving equivalent diet (as described in Reference [10]). Briefly, organic rearing differed from the conventional one in the availability of outdoor area $\left(100 \mathrm{~m}^{2}\right)$, the organic origin of ingredients used in feed mixture, and the lack of synthetic aminoacids and supplementation with alfalfa hay. All pigs were slaughtered in the same abattoir. After overnight cooling of carcasses, subcutaneous backfat, and meat from their front legs were shipped to the salami producer and processed the same day. Meat and backfat (representing $20 \%$ of the batter) were grinded on a $10 \mathrm{~mm}$ diameter mincing plate. Equal amounts of dried garlic $(0.6 \mathrm{~g} / \mathrm{kg})$, ground pepper $(1.0 \mathrm{~g} / \mathrm{kg})$, salt $(25 \mathrm{~g} / \mathrm{kg})$, and dextrose $(2.6 \mathrm{~g} / \mathrm{kg})$ were added to meat batters, mixed thoroughly, and filled into collagen casings $55 \mathrm{~mm}$ in diameter. Neither nitrites nor starter cultures were added to the batters. The prepared fresh sausages were put into the same drying/ripening chamber, where they were processed according to the usual practice of the processor. Initially (first week), they were held at $18{ }^{\circ} \mathrm{C}$ and relative air humidity of $82-88 \%$. Thereafter, they were 
held at $12-14{ }^{\circ} \mathrm{C}$ and relative air humidity of 78-85\% for 60 days. Sausages from both treatment groups were processed simultaneously, i.e., under standardized conditions of the same chamber. Randomly selected sausages were tested by accredited laboratory of Veterinary Faculty, University of Ljubljana for the presence of foodborne pathogens Staphylococcus aureus and other coagulase positive cocci [11], Clostridium perfringens [12], Listeria monocytogenes [13], Salmonella spp. [14], and Yersinia enterocolitica (bacteriological culture test). The shelf-life of sausages was not examined. At the end of the processing, 12 sausages (six per treatment group) were randomly selected for further analyses, vacuum packed, and frozen at $-80^{\circ} \mathrm{C}$ (for volatile compounds analysis) or $-20^{\circ} \mathrm{C}$ (other analysis).

Chemical composition and volatile profile analysis were performed (in duplicate) on 12 dry-fermented sausages (six per treatment group) pulverized in liquid nitrogen. For determining sample $\mathrm{pH}, 1 \mathrm{~g}$ of sample was mixed with $4 \mathrm{~mL}$ of distilled water and the $\mathrm{pH}$ value measured using Seven2Go pH meter equipped with electrode (Mettler Toledo GmbH, Schwarzenbach, Switzerland). The content of moisture, fat and proteins, index of proteolysis (as \% of non-protein nitrogen to total nitrogen), and water activity (aw) were determined as previously described [15]. To assess protein and lipid oxidation, protein carbonyl content and thiobarbituric acid reactive substances (TBARS) were determined (as previously described in References [16,17], respectively). Fatty acid composition (total and free) of dry-fermented sausage samples was analyzed in an accredited laboratory (Nutricontrol, Veghel, the Netherlands). Shortly, fat was saponified and the fatty acids esterified by the addition of methanol and boron trifluoride (BF3). Capillary gas chromatography, coupled by a flame ionization detector, was used for analysis of the resulting methyl esters. After completing the analysis of total fatty acids, the procedure was repeated without BF3 to detect bound fatty acids. Free fatty acid profile was calculated from the differences between the two runs. Volatile compounds were analyzed using solid phase microextraction (SPME), gas chromatography, and mass spectrometry (as described in Reference [18]).

For instrumental texture measurements, equal parallelepipeds $(1.5 \times 2 \times 2 \mathrm{~cm}$ for height, weight, and length, respectively, four from each of 12 sampled sausages) were cut from the central part of the sausages. Stress relaxation (SR) and texture profile analysis (TPA) tests were carried out with the use of TA Plus texture analyzer apparatus (Ametek Lloyd Instruments, Ltd., Bognor Regis, UK) as described in Reference [19]. In the case of SR test, samples were compressed for $25 \%$ of their original height for $90 \mathrm{~s}$ and a force decay coefficient calculated as (F0-F90)/F0, where F0 is the initial force recorded at maximum compression and F90 the force measured $90 \mathrm{~s}$ after. For TPA test, the samples were compressed twice to $50 \%$ of their original height and the parameters hardness, cohesiveness, gumminess, springiness, chewiness, and adhesiveness were calculated, based on the data from the force-time curves recorded during the compression. For both tests, the mean value of the four technical repetitions within each sausage was calculated and used for statistical comparison.

Sensory analysis was performed on 12 (six per treatment group) dry-fermented sausages using a quantitative descriptive analysis and a panel of six male and six female trained panelists. The panel members, all employed at Agricultural Institute of Slovenia, were nonsmokers, 23-57 years old. The panel was trained using different commercially available dry-cured sausages characterized by different range of texture, tastes, and maturity to familiarize with the variation in sensory properties. During three training sessions, 15 sensory descriptors were defined describing texture (juiciness, softness, crumbliness, pastiness), color (intensity, vividness), taste (off-tastes, bitterness, rancidity, sweetness, spiciness, saltiness, sourness), and smell (typical mature smell, smell intensity). The panelists were asked not to eat or drink (except water) $2 \mathrm{~h}$ prior to each session. During each sensory session, panel members evaluated two sausages per treatment, and they received two $3 \mathrm{~mm}$ thick slices per sausage. Each sausage was evaluated twice (in two rounds of sessions) by each panelist. Descriptors were scored on a $9 \mathrm{~cm}$ non-structured scale, anchored at both extremes (i.e., "intensive sensation" on the right and "not detected" on the left side).

Statistical analysis consisted of one-way analysis of variance with treatment group as main effect (organic or conventional pork), using GLM procedure of SAS statistical software (SAS Institute Inc., 
Cary, NC, USA). In the case of sensory traits, repeated measures analysis (using panelist as random effect) was conducted using procedure MIXED of SAS. The difference between means (Tukey t-test) was considered significant at $p<0.05$.

\section{Results}

The dry-fermented sausages were analyzed for the presence of foodborne pathogens Staphylococcus aureus and other coagulase positive cocci, Clostridium perfringens, Listeria monocytogenes, Salmonella spp., and Yersinia enterocolitica (bacteriological culture test), and the results were negative for all the tests.

\subsection{Physicochemical Traits}

At the end of processing, dry-fermented sausages made of meat from organic pigs had lower processing losses than sausages from conventional pigs, which resulted in the higher aw and moisture content (Table 1). Sausages from organically raised pigs had also lower $\mathrm{pH}$, lower salt $(\mathrm{NaCl})$ content, higher TBARS, and a tendency $(p<0.10)$ for higher carbonyl content. There were no differences observed for fat and protein content or index of proteolysis.

Table 1. Physicochemical traits of dry-fermented sausages (six per treatment group) manufactured without nitrite addition from pigs fattened in conventional or organic system.

\begin{tabular}{ccccc}
\hline Physicochemical Traits & Organic & Conventional & RMSE & \multicolumn{2}{c}{ Significance } \\
\hline Weight loss during processing, $\%$ & 32.8 & 37.1 & 0.63 & $* * *$ \\
Water activity (aw) & 0.910 & 0.868 & 0.0098 & $* * *$ \\
Moisture, $\%$ & 31.3 & 26.7 & 0.40 & $* * *$ \\
Fat, g/kg DM & 599 & 593 & 14.2 & $\mathrm{NS}$ \\
Protein, g/kg DM & 329 & 327 & 13.52 & $\mathrm{NS}$ \\
pH & 5.83 & 6.27 & 0.082 & NS \\
Proteolysis index, $\%$ & 9.2 & 9.6 & 1.51 & $*$ \\
NaCl, g/kg DM & 64.7 & 67.5 & 3.78 & $*$ \\
TBARS, $\mu$ g MDA/kg DM & 87.8 & 80.5 & 3.17 & + \\
\hline
\end{tabular}

RMSE $=$ Root mean square error. DM $=$ Dry matter. TBARS $=$ Thiobarbituric acid reactive substances. MDA = Malondialdehyde. Significance: NS $-p>0.10,+-p<0.10,{ }^{*}-p<0.05,{ }^{* *}-p<0.01,{ }^{* * *}-p<0.001$.

\subsection{Fatty Acids Analysis}

Fatty acids (FA) profile (Table 2 ) showed that dry-fermented sausages from organic pork contained more PUFA $(p<0.001)$ attributable to C18:2n-6, the most abundant FA in this group, but also to C18:3 $\mathrm{n}-3$ and C20:4n-6. Dry-fermented sausages from organic pork contained less SFA $(p<0.001)$ and MUFA $(p<0.001)$, mainly attributable to differences in C16:0 and C18:0, the most abundant among SFA, and C18:1n-9, the most abundant MUFA, and C20:1n-9. The levels of C16:1n7 and C17:1 (both MUFA) were, however, higher in dry-fermented sausages from organic pork $(p<0.05)$. Dry-fermented sausages from organic pork exhibited also lower amounts of free fatty acids $(p<0.001)$, owing to SFA $(p<0.001)$, MUFA $(p<0.001)$ or PUFA $(p=0.01)$. The difference in free fatty acids is mostly due to C18:1n-9 (the most abundant) with $33 \%$ lower amounts observed in dry-fermented sausages from organic than conventional pork. 
Table 2. Fatty acid and free fatty acid composition (g/100 g fat) of dry-fermented sausages (six per treatment group) manufactured without nitrite addition from organic and conventional pork.

\begin{tabular}{|c|c|c|c|c|}
\hline Fatty Acid Composition & Organic & Conventional & RMSE & Significance \\
\hline \multicolumn{5}{|l|}{ Fatty acids } \\
\hline C14:0 & 1.40 & 1.30 & 0.000 & $* * *$ \\
\hline C16:0 & 24.70 & 25.17 & 0.131 & $* *$ \\
\hline C16:1n7 & 2.28 & 2.17 & 0.065 & $* *$ \\
\hline C17:0 & 0.70 & 0.70 & 0.045 & NS \\
\hline C17:1 & 0.38 & 0.30 & 0.029 & $* *$ \\
\hline C18:0 & 13.67 & 14.37 & 0.144 & $* * *$ \\
\hline C18:1n-9 & 37.75 & 38.65 & 0.207 & $* * *$ \\
\hline C18:1 other & 3.08 & 3.07 & 0.079 & NS \\
\hline C18:2n-6 & 12.38 & 10.85 & 0.246 & $* * *$ \\
\hline C18:3 n-3 & 0.85 & 0.68 & 0.048 & $* * *$ \\
\hline C20:1n-9 & 0.80 & 0.92 & 0.029 & $* * *$ \\
\hline C20:4n-6 & 0.28 & 0.22 & 0.002 & $* *$ \\
\hline SFA & 41.00 & 41.98 & 0.291 & $* * *$ \\
\hline MUFA & 44.18 & 44.98 & 0.271 & $* *$ \\
\hline PUFA & 14.47 & 12.65 & 0.288 & $* * *$ \\
\hline \multicolumn{5}{|l|}{ Free fatty acids } \\
\hline $\mathrm{C} 14: 0$ & 0.07 & 0.08 & 0.008 & $* *$ \\
\hline $\mathrm{C} 16: 0$ & 0.67 & 1.08 & 0.105 & $* * *$ \\
\hline C18:0 & 0.25 & 0.37 & 0.054 & $* *$ \\
\hline C18:1n-9 & 1.58 & 2.37 & 0.202 & $* * *$ \\
\hline C18:1 other & 0.17 & 0.23 & 0.024 & $* *$ \\
\hline C18:2n-6 & 0.96 & 1.06 & 0.066 & $*$ \\
\hline$C 18: 3 n-3$ & 0.07 & 0.07 & 0.006 & NS \\
\hline C20:1n-9 & nd & 0.07 & & \\
\hline$C 20: 2 n-6$ & 0.07 & 0.08 & 0.008 & * \\
\hline$C 20: 4 n-6$ & 0.01 & 0.03 & 0.028 & NS \\
\hline$C 22: 3 n-3$ & 0.06 & 0.07 & 0.023 & NS \\
\hline C24:1n-9 & 0.02 & 0.04 & 0.035 & NS \\
\hline SFA & 0.98 & 1.23 & 0.164 & $* * *$ \\
\hline MUFA & 1.90 & 2.86 & 0.232 & $* * *$ \\
\hline PUFA & 1.17 & 1.31 & 0.088 & $*$ \\
\hline Total & 4.05 & 5.70 & 0.476 & $* * *$ \\
\hline
\end{tabular}

SFA $=$ Saturated fatty acids. MUFA $=$ Monounsaturated fatty acids. PUFA $=$ Polyunsaturated fatty acids. RMSE $=$ Root mean square error. $n d=$ not detected. Significance: NS $-p>0.10, *-p<0.05,{ }^{* *}-p<0.01$, $* * *-p<0.001$.

\subsection{Volatiles Profile Analysis}

There were 66 individual volatile compounds identified in dry-fermented sausages (Table 3). Classification of volatiles according to the most probable origin [20] showed that the most abundant were those deriving from the spices, followed by the volatiles generated by microbial carbohydrate fermentation, lipid autooxidation, esterase activity, degradation of amino acids, and lipid $\beta$-oxidation, accounting for $33.7 \%, 23.3 \%, 13.7 \%, 13.2 \%, 10.3 \%$, and $5.9 \%$ of relative abundance/total area, respectively.

As depicted in Figure 1, dry-fermented sausages from organic pork had lower levels $(p=0.017)$ of total volatile compounds than sausages from conventional pork. This effect was most notable for the volatiles originating from spices $(p<0.001)$ and was observed for 16 out of 20 identified substances (most markedly for limonene, sabinene, $\alpha$-phellandrene, and terpenes as the most abundant compounds within this group). Dry-fermented sausages from pork of organic system were also characterized by lower $(p=0.008)$ level of volatiles generated by amino acid degradation. This was observed for several individual volatiles from this group (i.e., benzenacetaldehyde, benzenaldehyde 3-methyl butanal), while 2-methyl propanol and methional were not identified in the sausages from organic pork. With regard to the volatiles originating from lipid $\beta$-oxidation, their higher abundance 
$(p=0.006)$ was observed in the sausages from organic pork, the difference being mostly attributable to (R)-2-butanol. There were no differences between the sausages in volatiles originating from carbohydrate fermentation, although several individual compounds were found in either higher (i.e., acetic acid, 2-butanone) or lower (i.e., ethanol, acetone, 3-hydroxy-2-butanone) amounts in sausages from organic pigs $(p<0.05)$. Similarly, mainly no significant differences $(p>0.05)$ between dry-fermented sausages from organic and conventional pork were observed for volatiles generated by lipid autooxidation, though some individual volatiles were affected (i.e., 2-pentyl-furan and pentanal had higher, whereas nonanal had lower abundance in sausages from organic pigs, $p<0.05$ ).
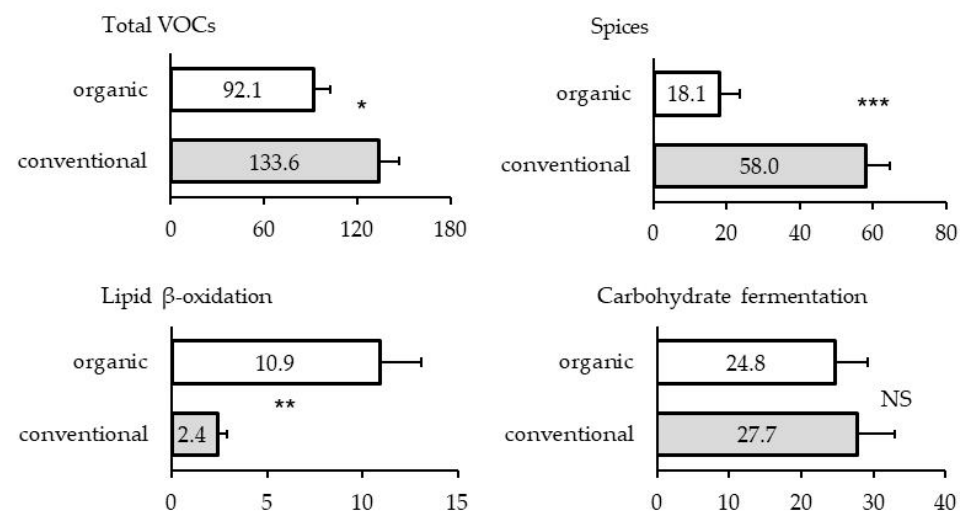
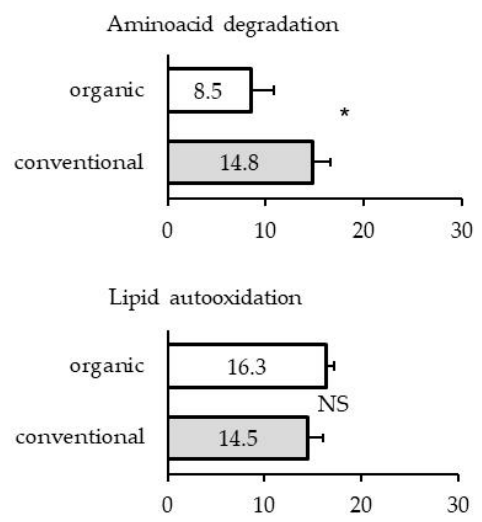

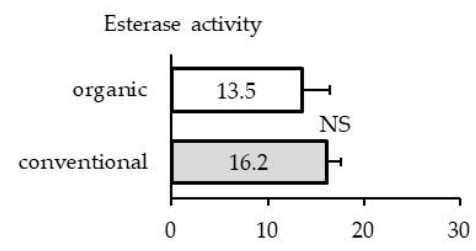

Figure 1. Relative abundance of groups of volatile compounds (VOCs) in dry-fermented sausages (six per treatment group) according to pig husbandry practice (organic or conventional). (NS $-p>0.10$, $\left.{ }^{*}-p<0.05,{ }^{* *}-p>0.01,{ }^{* * *}-p<0.001\right)$.

Table 3. Volatile compounds (expressed as normalized area (Area Comp/Area IS); IS=2-methyl-3-heptanone) of dry-fermented sausages (six per treatment group) manufactured without nitrite addition made of pork from organic or conventional husbandry system.

\begin{tabular}{|c|c|c|c|c|c|c|}
\hline Supposed Origin of Volatiles & LRI & RI & Organic & Conventional & RMSE & Significance \\
\hline \multicolumn{7}{|l|}{ Spices } \\
\hline Allyl mercaptan & 610 & $\mathrm{~b}$ & 0.43 & 0.37 & 0.163 & NS \\
\hline Allyl methyl sulphide & 718 & $\mathrm{a}$ & 4.43 & 5.69 & 1.004 & + \\
\hline (Z)-1-(methylthio) 1-propene & 759 & $\mathrm{~b}$ & 0.40 & 0.28 & 0.062 & $* *$ \\
\hline Allyl sulfide & 883 & a & 0.15 & 0.42 & 0.178 & $*$ \\
\hline Terpene & 934 & $\mathrm{a}$ & 1.14 & 4.21 & 0.885 & $* * *$ \\
\hline$\alpha$-pinene & 940 & a & 0.63 & 2.37 & 0.501 & $* * *$ \\
\hline Sabinene & 986 & a & 3.25 & 12.80 & 2.518 & $* * *$ \\
\hline$\beta$-myrcene & 1003 & a & 0.25 & 2.01 & 0.375 & $* * *$ \\
\hline$\alpha$-phellandrene & 1022 & a & 1.24 & 8.39 & 1.555 & $* * *$ \\
\hline a-terpinene & 1034 & $\mathrm{a}$ & 0.19 & 0.76 & 0.159 & $* * *$ \\
\hline Limonene & 1045 & $\mathrm{a}$ & 3.70 & 15.09 & 2.902 & $* * *$ \\
\hline Terpene & 1050 & $\mathrm{~b}$ & 0.92 & 5.04 & 1.442 & $*$ \\
\hline$\gamma$-terpinene & 1074 & $\mathrm{~b}$ & 0.28 & 1.01 & 0.201 & $* * *$ \\
\hline Terpene & 1099 & $\mathrm{~b}$ & nd & 0.09 & / & / \\
\hline Terpinolene & 1101 & $\mathrm{a}$ & 0.09 & 0.47 & 0.095 & $* * *$ \\
\hline Diallyl disulphide & 1119 & $\mathrm{a}$ & 0.20 & 0.20 & 0.042 & NS \\
\hline 1,2-dimethoxy-Benzene & 1197 & $\mathrm{~b}$ & 0.07 & 0.11 & 0.027 & * \\
\hline
\end{tabular}


Table 3. Cont.

\begin{tabular}{|c|c|c|c|c|c|c|}
\hline Supposed Origin of Volatiles & LRI & RI & Organic & Conventional & RMSE & Significance \\
\hline Toluene & 788 & $\mathrm{a}$ & 0.10 & 0.15 & 0.050 & NS \\
\hline Copaene & 1403 & $\mathrm{~b}$ & 0.21 & 0.37 & 0.068 & $* *$ \\
\hline Caryophyllene & 1434 & $\mathrm{a}$ & 0.78 & 1.65 & 0.295 & $* * *$ \\
\hline \multicolumn{7}{|l|}{ Aminoacid degradation } \\
\hline Benzaldehyde & 1018 & $\mathrm{a}$ & 1.15 & 3.64 & 0.861 & $* *$ \\
\hline Benzeneacetaldehyde & 1111 & $\mathrm{a}$ & 7.10 & 10.29 & 2.307 & * \\
\hline 2-Methyl propanal & 592 & $\mathrm{a}$ & nd & 0.08 & & \\
\hline 3-Methyl butanal & 689 & $\mathrm{a}$ & 0.25 & 0.99 & 0.287 & $* *$ \\
\hline Methional & 966 & a & nd & 0.10 & & \\
\hline \multicolumn{7}{|l|}{ Lipid $\beta$-oxidation } \\
\hline Isopropyl alcohol & 537 & a & 0.24 & 0.39 & 0.094 & * \\
\hline (R)-2-Butanol & 642 & $\mathrm{a}$ & 9.90 & 1.54 & 4.182 & $* *$ \\
\hline 2-Pentanone & 733 & $\mathrm{a}$ & 0.17 & 0.18 & 0.050 & NS \\
\hline 1-Octen-3-ol & 1031 & a & 0.51 & nd & & \\
\hline 2-Octanone & 1039 & $\mathrm{a}$ & 0.10 & 0.10 & 0.027 & NS \\
\hline 2-Nonanone & 1140 & $\mathrm{a}$ & 0.22 & 0.30 & 0.109 & NS \\
\hline \multicolumn{7}{|l|}{ Carbohydrate fermentation } \\
\hline Ethyl alcohol & 505 & $\mathrm{a}$ & 2.66 & 3.86 & 0.715 & * \\
\hline Acetaldehyde & 466 & $\mathrm{a}$ & 0.07 & 0.11 & 0.036 & + \\
\hline Acetic acid & 711 & a & 6.93 & 4.80 & 1.374 & * \\
\hline Acetone & 527 & $\mathrm{a}$ & 2.33 & 12.76 & 7.668 & * \\
\hline 2-Butanone & 630 & $\mathrm{a}$ & 11.51 & 3.57 & 3.287 & $* *$ \\
\hline 3-Hydroxy-2-butanone & 779 & $\mathrm{a}$ & 0.41 & 1.51 & 0.606 & * \\
\hline Butanoic acid & 887 & $\mathrm{a}$ & 0.85 & 1.11 & 0.417 & NS \\
\hline \multicolumn{7}{|l|}{ Lipid autooxidation } \\
\hline 1-Propanol & 611 & $\mathrm{a}$ & 0.76 & 0.93 & 0.532 & NS \\
\hline Propanal & 523 & $\mathrm{a}$ & 0.09 & 0.07 & 0.034 & NS \\
\hline 2-Pentyl-furan & 1009 & $\mathrm{a}$ & 0.09 & 0.05 & 0.011 & $* *$ \\
\hline Pentane & 500 & $\mathrm{a}$ & 2.29 & 2.06 & 0.698 & NS \\
\hline Pentanal & 738 & $\mathrm{a}$ & 0.34 & 0.29 & 0.085 & $*$ \\
\hline Hexane & 600 & $\mathrm{a}$ & 0.94 & 1.10 & 1.015 & NS \\
\hline 1-Hexanol & 923 & a & 0.47 & 0.05 & 0.253 & NS \\
\hline Hexanal & 840 & $\mathrm{a}$ & 5.13 & 4.29 & 1.578 & NS \\
\hline Heptane & 700 & $\mathrm{a}$ & 2.42 & 2.45 & 0.610 & NS \\
\hline (Z)-2-Heptenal & 1011 & a & nd & 0.19 & & \\
\hline Octane & 800 & $\mathrm{a}$ & 2.95 & 2.62 & 0.638 & NS \\
\hline Octanal & 1049 & $\mathrm{a}$ & 0.19 & nd & & \\
\hline Octanoic acid & 1264 & a & 0.03 & 0.05 & 0.018 & NS \\
\hline Nonanal & 1149 & $\mathrm{a}$ & 0.47 & 0.62 & 0.114 & $*$ \\
\hline \multicolumn{7}{|l|}{ Esterase activity } \\
\hline Methyl acetate & 549 & $\mathrm{a}$ & 4.76 & 5.04 & 1.363 & NS \\
\hline Ethyl acetate & 634 & $\mathrm{a}$ & 0.71 & 0.48 & 0.228 & NS \\
\hline Methyl propionate & 650 & $\mathrm{a}$ & 0.89 & 1.31 & 0.763 & NS \\
\hline Methyl butanoate & 755 & $\mathrm{a}$ & 3.19 & 5.00 & 1.821 & NS \\
\hline Methyl 2-hydroxypropanoate & 792 & $a$ & 0.20 & 0.13 & 0.047 & $*$ \\
\hline Methyl 3-methylbutanoate & 805 & a & 0.96 & 1.31 & 0.576 & NS \\
\hline Ethyl butanoate & 830 & $\mathrm{a}$ & 0.51 & 0.70 & 0.147 & NS \\
\hline Methyl pentanoate & 855 & $\mathrm{a}$ & 0.13 & 0.13 & 0.029 & NS \\
\hline Propyl butanoate & 925 & $\mathrm{a}$ & nd & 0.09 & & \\
\hline Methyl hexanoate & 951 & $\mathrm{a}$ & 1.53 & 1.63 & 0.373 & NS \\
\hline Methyl heptanoate & 1057 & $\mathrm{a}$ & 0.07 & 0.05 & 0.014 & + \\
\hline Methyl octanoate & 1156 & $\mathrm{a}$ & 0.78 & 1.16 & 0.352 & + \\
\hline Methyl nonanoate & 1260 & $\mathrm{a}$ & nd & 0.14 & & \\
\hline Methyl decanoate & 1358 & $\mathrm{a}$ & 0.14 & 0.24 & 0.127 & NS \\
\hline
\end{tabular}

LRI = Linear retention index for DB-624 column. RI = Reliability of identification: a = Identification by mass spectrum and by coincidence with the LRI of an authentic standard, $b=$ Tentative identification by mass spectrum. RMSE $=$ Root mean square error. nd $=$ not detected. Significance: NS $-p>0.10,+-p<0.10,{ }^{*}-p<0.05,{ }^{* *}-p<0.01$, $* * *-p<0.001$ 


\subsection{Instrumental Texture Parameters}

Significant differences in some of instrumentally assessed texture properties (Table 4) were observed between dry-fermented sausages made of meat from organic or conventional pigs. The texture of dry-fermented sausages made of organic pork was softer, with lower cohesiveness, lower gumminess, and lower chewiness.

Table 4. Instrumental texture parameters of dry-fermented sausages (six per treatment group) manufactured without nitrite addition from pigs fattened in conventional or organic system.

\begin{tabular}{ccccc}
\hline Texture Parameter & Conventional & Organic & RMSE & Significance \\
\hline Force decay coefficient & 0.57 & 0.60 & 0.066 & NS \\
Hardness, N & 57.7 & 30.7 & 7.60 & $* * * *$ \\
Cohesiveness & 0.51 & 0.38 & 0.054 & $* * *$ \\
Gumminess, N & 29.9 & 11.9 & 5.90 & NS \\
Springiness, mm & 4.4 & 4.5 & 0.68 & $* * *$ \\
Chewiness, N & 135.3 & 53.8 & 33.98 & NS \\
Adhesiveness, N*mm & -2.5 & -2.9 & 1.10 & \\
\hline
\end{tabular}

RMSE $=$ Root mean square error. Significance: NS $-p>0.10,+-p<0.10,{ }^{*}-p<0.05,{ }^{* *}-p<0.01,{ }^{* * *}-p<0.001$.

\subsection{Sensory Analysis}

Results of sensory analysis of dry-fermented sausages from organic or conventional pork (Figure 2) also exhibited significant differences related to pig husbandry practice. The panelists scored the color of dry-fermented sausages from organic pigs as being less intensive and somewhat less vivid. The panelists perceived dry-fermented sausages from organic pigs as softer, crumblier, and juicier. As for the taste, panelists found dry-fermented sausages from organic pork as being more bitter, sourer, and slightly more rancid. Dry-fermented sausages from meat of organic pigs received also higher average score for off-tastes.

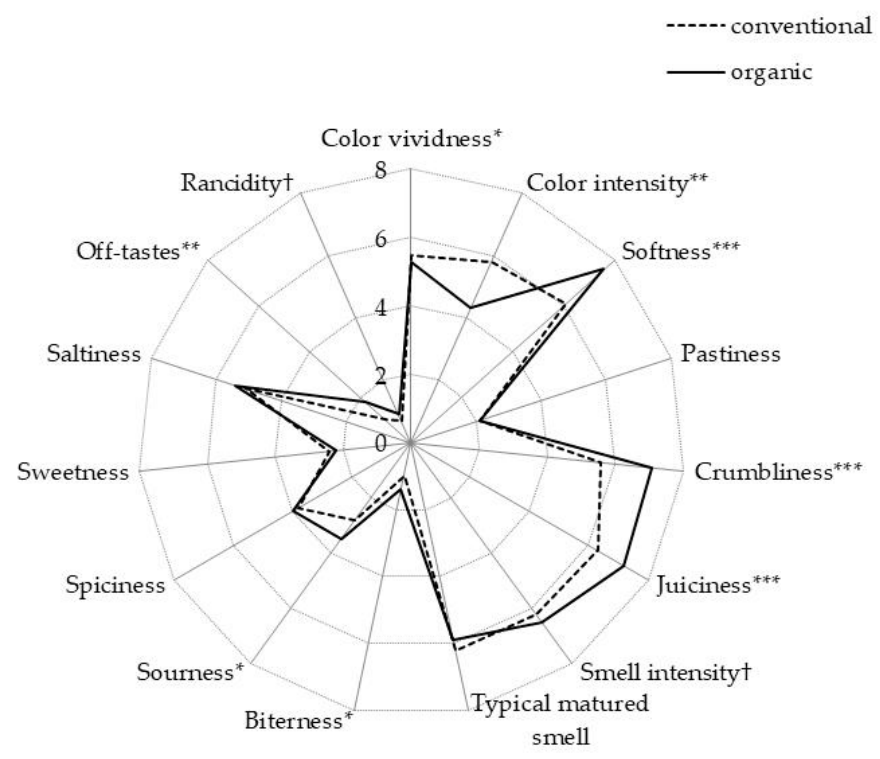

Figure 2. Sensory profile of dry-fermented sausages (six per treatment group) manufactured without nitrite addition from pigs fattened in conventional or organic system (NS $-p>0.10, *-p<0.05$, ** $\left.-p>0.01,{ }^{* * *}-p<0.001\right)$. 


\section{Discussion}

Physical-chemical properties of dry-fermented sausages manufactured without nitrite addition differed with regard to organic or conventional husbandry origin of meat. Higher moisture content (along with higher water activity) can be ascribed to lower processing losses in the sausages from organic pork. Considering that fat content was similar in both sausage groups, lower processing losses in the case of organic sausages can be explained with fatty acid composition, namely, higher PUFA content. More unsaturated fats are prone to exudation from the adipose tissue cells, covering the meat particles inside the sausage and causing oiliness on the product surface, which prevents the product from drying [21]. Differences in $\mathrm{pH}$ values might be due to the meat intrinsic properties and/or microbial fermentation. It was shown [22] that spontaneous fermentation is characterized by richer microbial diversity, delayed lactic acid bacteria evolution, and lower $\mathrm{pH}$ decline (slow fermented sausages have generally milder $\mathrm{pH}$ declines). The $\mathrm{pH}$ value was already lower at start in organic than conventional meat mixture (6.10 vs. 6.24). However, for sausages, the meat from front legs was used (composed of more oxidative muscles with higher $\mathrm{pH}$ ), the differences in $\mathrm{pH}$ were also evidenced in glycolytic longissimus dorsi muscle of the same pigs [10]. Different $\mathrm{pH}$ of meat batter at start has likely affected the development of the autochthonous microflora (no starter cultures were used) and, consequently, the fermentation process [6]. However, as no analysis of main microbiota populations were carried out, it is difficult to make any further conclusions. The observed differences in salt content between organic and conventional group are difficult to explain. Overall the difference, although significant, is small (i.e., less than $0.3 \%$ points) and could be due to low intra-group variability. Higher oxidation levels observed for organic sausages, either of protein (i.e., carbonyls) or lipids (i.e., TBARS), could also be associated with higher PUFA levels [23,24]. Although TBARS concentrations are not proportional to protein carbonyl concentrations measured by dinitrophenylhydrazine (DNPH) method (as in our case), they are, in general, positively correlated [25] because lipid oxidation is one of the main factors governing the oxidation of proteins and amino acids [23,24]. In addition, oxidation processes in dry-fermented sausages may be stimulated by several other factors including lower $\mathrm{pH}$ value [20], as observed in organic compared to conventional sausages. The observed effect confirms the result of our previous report [18], just that the level of oxidation was higher (by 30 and 58\% for TBARS and carbonyls, respectively) due to nitrites absence, as the nitrites are potent antioxidants.

With regard to fatty acid composition, higher levels of PUFA (in parallel to lower SFA) observed in organic sausages may be attributed to the differences in the diet, namely, the supplementation with alfalfa hay, rich in polyunsaturated fats. The share of PUFA in total fatty acids of the alfalfa hay represents more than 60\% [26]. Higher PUFA in fat from organic or outdoor reared pigs with access to green feed agrees with the results of other studies $[27,28]$. Additionally, lower fat saturation in organically raised pigs may also be due to higher physical activity, as shown for rats [29,30], but also in pigs [31], i.e., exercised Iberian pigs exhibiting lower SFA in the backfat, higher PUFA in neutral fat of Psoas major muscle than sedentary ones, despite being fed the same diet. Sausages from organic pork had also lower amounts of FFA than conventional ones. This may indicate lower level of lipolysis or higher level of FFA oxidative degradation (in line with higher TBARS) in organic sausages. As reviewed by Reference [21], lipolysis and lipid oxidation are not positively associated, indications exist that lipolysis even prevents FFA from oxidation, which may additionally explain the differences between organic and conventional sausages of the present study. In fermented meat products with high $\mathrm{pH}$ (case of conventional group), lipases from very lipolytic species of Staphylococcus could increase lipolysis [32]. In general, the factors affecting lipase activity are insufficiently explained, either in regard to ante mortem factors, like pig weight or diet [21], or in relation to meat batter formulation (additives, $\mathrm{pH}$ [33]). A decrease of neutral lipase activity was likely due to lower $\mathrm{pH}$ and may also be associated to moderate exercise of pigs [31], which could explain lower lipolysis in sausages from organic pigs. On the contrary, the activities of acid lipase and esterase are increased with lower $\mathrm{pH}$, salt concentration, and aw reduction [34], which might explain higher lipolysis in conventional sausages of the present study. 
Differences in volatile compounds may be attributable to microbial and/or endogenous enzymes, however, as the microbial populations were not examined in the present study, it is not possible to ascertain if and to which degree the differences in volatiles derive from microbial metabolism or other processes like auto-oxidation or endogenous enzyme activity. It can, however, be speculated that when higher concentrations of volatiles classified as products of microbial lipid $\beta$-oxidation are found, microbial growth and/or metabolism must have been stimulated by milieu conditions such as $\mathrm{pH}$, salt content, and moisture [6]. Moreover, since the sausages were made without nitrites, it is likely that the differences between sausages made from organic or conventional pork were exacerbated due to the absence of antioxidant and anti-microbial function of nitrites [4,35]. As for individual volatile groups, the most notable and uniform difference between sausages from organic and conventional pork was found for volatiles originating from the added spices (namely, garlic and pepper), indicating app. three-fold reduction in organic compared to conventional sausages. One explanation may be their higher degradation in organic sausages due to more oxidative conditions, indicated by oxidation markers carbonyls and TBARS as well as higher concentrations of PUFA. Many compounds of spices (for example, terpenoids) are relatively unstable [36] and disposed to oxidation as shown, for instance, on black pepper oleoresin [37]. Initially formed oxidation products from terpenoids were also reported to decompose upon increasing acidity, while volatile stability may also be compromised by the presence of moisture [36]. In the present case, both factors were more pronounced in the sausages from organic pork. Furthermore, for garlic extracts (thiosulfanates), decreasing stability was reported with increasing degree of fatty acid unsaturation [38]. Garlic extracts were also found to be surprisingly unstable when stored in liquid vegetable oil [39], which has high PUFA. Although there was no difference in proteolysis (i.e., proteolysis index) noted between sausages from organic and conventional pork, we could observe that sausages from organic meat had lower amounts of volatiles originating from amino acid degradation. The reasons for that may be in more specific proteolytic degradation of either endogenous or microbial enzymes. In support of present study results, the research on the Iberian breed [40] demonstrated that exercised pigs, in comparison to sedentary ones, expressed lower activity of some muscle proteolytic enzymes and lower branched chain amino acids levels, but no differences in total free amino acids. Branched chain amino acids act as precursors for Strecker aldehydes which contribute to flavor of dry-fermented sausages [41]. One (3-methyl-butanal) was detected at lower levels in sausages from organic pork. A similar result was observed for the most abundant volatile compound from this group, benzenacetaldehyde, originating from Strecker degradation of phenylalanine [42]. The Strecker degradation is favored by low aw [7] and the higher concentrations of precursor free amino acids (generated by aminopeptidases, enzymes with lower activity at lower $\mathrm{pH}$ [6]) which explains lower levels amino acid-derived volatiles in sausages from organic pork.

Instrumental texture differences match closely the moisture content, which can be explained by fat unsaturation and its effect on dehydration process. Less saturated fat with its softer consistency [43] could also have directly affected the softer texture of sausages from organically raised pigs.

Regarding sensory analysis, color intensity (lower in sausages from organic pork), juiciness, softness, and crumbliness (higher in sausages from organic pork) corroborate with higher moisture content. Lower color intensity and vividness of sausages from organic pork can be associated to higher level of oxidation, namely, oxidative processes of lipids associated to the formation of yellow colored polymers [44] and discolorations due to the oxidation of muscle pigment myoglobin that can be enhanced either by lipid oxidation products or directly by lower $\mathrm{pH}$ [45]. Higher sourness of sausages from organic pork can be related to either higher acetic acid content or lower $\mathrm{pH}$ value. Higher off-taste scores, along with higher rancidity, were observed in sausages from organic pork, which were more prone to oxidation and agrees with higher TBARS and carbonyl concentrations. Although there was no significant difference in smell intensity or typicity, we could note lower total volatile compounds (VOCs) along with higher score for (negative) taste attributes, such as bitterness, sourness, rancidness, and off-tastes in sausages from organic pork. Higher off-taste scores in sausages 
from organic pork can be aligned with lower levels of volatiles originating from spices or higher levels of other specific volatiles. This includes 2-pentyl-furan (characterized by rancid, onion, savory, stable, sulfur [7]), pentanal (characterized by strong pungent, rancid, green notes [7,46]), acetic acid and 2-butanol (characterized by vinegar, sour or winey notes [7,47]), or 2-butanone (associated to ethereal note [47]). In addition, sausages from organic pork exhibited also lower levels of volatiles characterized by more positive aroma notes, like 3-hydroxy-2-butanone (buttery, sweet caramel, yogurt [7,48,49]), 3-methyl butanal (fruity, cheesy, malty, cured, green, acorn [7,47]), acetaldehyde (green [7]), ethyl alcohol (sweet, alcohol, bread, yeast [7,47]), benzenacetaldehyde (musk, jasmine, rancid [50]), and benzaldehyde (bitter almonds, herbal, spices, pine [7]).

\section{Conclusions}

Organically reared pork was characterized by lower meat $\mathrm{pH}$ and higher fat unsaturation, which led to higher moisture retention and higher levels of oxidation in dry-fermented sausages, resulting in softer texture, less intensive color, and changed volatile profile (less volatiles originating from spices and amino acid degradation, more from lipid $\beta$-oxidation) and sensory quality (higher presence of sour, bitter, rancid, and off-tastes). It is possible that, in the present study, the effect was more pronounced because the sausages were produced without nitrites and starter cultures. More studies are needed with organic pork and use of natural antioxidants to reply to consumer demand for more traditional and natural products.

Author Contributions: Conceptualization, M.Š. and M.Č.P.; Methodology, U.T., M.̌̌.; M.F.; Validation, M.̌̌., M.Č.P., M.F., Formal analysis, M.Š., M.Č.P., N.B.-L., U.T., and M.F.; Investigation, M.Š., M.Č.P., N.B.-L., U.T., M.F.; Resources, M.Š., M.Č.P., N.B.-L., U.T., M.F.; Data curation, M.Š., M.Č.P.; Writing—original draft preparation, M.Š., M.Č.P.; Writing—review and editing, M.Š., M.Č.P., N.B.-L., U.T., M.F.; Visualization, M.Š.; Supervision, M.Č.P., M.F.; Project administration, M.Č.P.; Funding acquisition, M.Č.P., M.F.

Funding: This research was funded by EUROPEAN UNION'S HORIZON 2020 RESEARCH AND INNOVATION PROGRAMME under grant agreement No 634476 (Project acronym TREASURE). The content of this paper reflects only the authors' view and Research Executive Agency is not responsible for any use that may be made of the information it contains. Additional financial support was provided by SLOVENIAN RESEARCH AGENCY (grants P4-0133 and V4-1417), Slovenian Ministry of Agriculture, Food and Forestry (V4-1417) and from AGL2015-64673-R (MINEICO, Spain) and FEDER funds.

Acknowledgments: The authors would like to thank meat processing plant KZ Tolmin z.o.o. Salamerija Alpija for manufacturing of dry-fermented sausages.

Conflicts of Interest: The authors declare no conflict of interest. The funders had no role in the design of the study; in the collection, analyses, or interpretation of data; in the writing of the manuscript, or in the decision to publish the results.

\section{References}

1. Pieniak, Z.; Verbeke, W.; Vanhonacker, F.; Guerrero, L.; Hersleth, M. Association between traditional food consumption and motives for food choice in six European countries. Appetite 2009, 53, 101-108. [CrossRef] [PubMed]

2. Sebranek, J.G.; Bacus, J.N. Cured meat products without direct addition of nitrate and nitrite: What are the issues? Meat Sci. 2007, 77, 136-147. [CrossRef] [PubMed]

3. Cassens, R.G. Composition and safety of cured meats in the USA. Food Chem. 1997, 59, 561-566. [CrossRef]

4. Alahakoon, A.U.; Jayasena, D.D.; Ramachandra, S.; Jo, C. Alternatives to nitrite in processed meat: Up to date. Trends Food Sci. Technol. 2015, 45, 37-49. [CrossRef]

5. Lücke, F.K. Utilization of microbes to process and preserve meat. Meat Sci. 1998, 56, 105-115. [CrossRef]

6. Toldrá, F.; Flores, M. Sausages, Types of: Dry and Semidry. In Encyclopedia of Meat Sciences; Devine, C., Dikeman, M., Eds.; Academic Press: Oxford, UK, 2014; pp. 248-255.

7. Flores, M.; Olivares, A. Flavor. In Handbook of Fermented Meat and Poultry; Toldrá, F., Ed.; John Wiley \& Sons: Chichester, West Sussex, UK, 2015; pp. 217-225. 
8. Commission regulation $889 / 2008$ of 5 September 2008 laying down detailed rules for the implementation of Council Regulation (EC) No 834/2007 on organic production and labelling of organic products with regard to organic production, labelling and control. Off. J. Eur. Union 2008, L 250, 1-84.

9. Kastelic, A.; Čandek-Potokar, M. Application of quality labels in support of conservation of local breeds-A challenge for Slovenian Krškopolje pig. Acta Agric. Slov. 2013, 4, 205-209.

10. Tomažin, U.; Batorek Lukač, N.; Škrlep, M.; Prevolnik Povše, M.; Čandek-Potokar, M. Meat and fat quality of Krškopolje pigs reared in conventional and organic production systems. Animal 2018. [CrossRef] [PubMed]

11. SO 6888-2; Microbiology of Food and Animal Feeding Stuffs-Horizontal Method for the Enumeration of Coagulase-Positive Staphylococci (Staphylococcus aureus and Other Species)_Part 2: Technique Using Rabbit Plasma Fibrinogen Agar Medium; International Organization for Standardization: Genève, Switzerland, 1999.

12. ISO/CD 15213; Microbiology of the Food and animal feeding stuffs - Horizontal method for the enumeration of sulfite-reducing bacteria growing under anaerobic conditions; International Organization for Standardization: Genève, Switzerland, 2003.

13. ISO 11290-1; Microbiology of the Food Chain-Horizontal Method for the Detection and Enumeration of Listeria monocytogenes and of Listeria spp.; International Organization for Standardization: Genève, Switzerland, 2017.

14. ISO 6579; Microbiology of Food and Animal Feeding Stuffs_Horizontal Method for the Detection of Salmonella spp.; International Organization for Standardization: Genève, Switzerland, 2002.

15. Škrlep, M.; Čandek-Potokar, M.; Batorek Lukač, N.; Prevolnik Povše, M.; Pugliese, C.; Labussière, E.; Flores, M. Comparison of entire male and immunocastrated pigs for dry-cured ham production under two salting regimes. Meat Sci. 2016, 111, 27-37. [CrossRef] [PubMed]

16. Rezar, V.; Salobir, J.; Levart, A.; Tomažin, U.; Škrlep, M.; Batorek Lukač, N.; Čandek-Potokar, M. Supplementing entire male pig diet with hydrolysable tannins: Effect on carcass traits, meat quality and oxidative stability. Meat Sci. 2017, 133, 95-102. [CrossRef] [PubMed]

17. Lynch, S.M.; Frei, B. Mechanisms of copper- and irondependent oxidative modification of human low-density lipoprotein. J. Lipid Res. 1993, 34, 1745-1751. [PubMed]

18. Škrlep, M.; Čandek-Potokar, M.; Tomažin, U.; Batorek Lukač, N.; Flores, M. Properties and aromatic profile of dry-fermented sausages produced from Krškopolje pigs reared under organic and conventional rearing regime. Animal 2018, 12, 1316-1323. [CrossRef] [PubMed]

19. Pugliese, C.; Sirtori, F.; Škrlep, M.; Piasentier, E.; Calamai, L.; Franci, O.; čandek-Potokar, M. The effect of ripening time on biochemical, textural, volatile and sensorial traits of Biceps femoris and Semimembranosus muscles of the Slovenian dry-cured ham Kraški pršut. Meat Sci. 2015, 100, 58-68. [CrossRef] [PubMed]

20. Ordoñez, A.; Hierro, E.M.; Bruna, J.M.; de la Hoz, L. Changes in the components of dry-fermented sausages during ripening. Crit. Rev. Food Sci. Nutr. 1999, 39, 329-367. [CrossRef] [PubMed]

21. Gandemer, G. Lipids in muscles and addipose tissues, changes during processing and sensory properties of meat products. Meat Sci. 2002, 62, 309-321. [CrossRef]

22. Ferrocino, I.; Bellio, A.; Giordano, M.; Macori, G.; Romano, A.; Rantsiou, K.; Decastelli, L.; Cocolina, L. Shotgun Metagenomics and Volatilome Profile of the Microbiota of Fermented Sausages. Appl. Environ. Microbiol. 2018, 84, e02120-17. [CrossRef] [PubMed]

23. Estévez, M. Protein carbonyls in meat systems: A review. Meat Sci. 2011, 89, 259-279. [CrossRef]

24. Lund, M.N.; Heinonen, M.; Baron, C.P.; Estévez, M. Protein oxidation in muscle foods: A review. Mol. Nutr. Food Res. 2011, 55, 83-95. [CrossRef]

25. Armenteros, M.; Heinonen, M.; Ollilainen, V.; Toldra, F.; Estévez, M. Analysis of protein carbonyls in meat products by using the DNPH-method, fluorescence spectroscopy and liquid chromatography-electrospray ionisation-mass spectrometry (LC-ESI-MS). Meat Sci. 2010, 83, 104-112. [CrossRef]

26. Boufaïed, H.; Chouinard, P.Y.; Tremblay, G.F.; Petit, H.V.; Michaid, R.; Bélanger, G. Fatty acids in forages. I. Factors affecting concentrations. Can. J. Anim. Sci. 2003, 83, 501-511. [CrossRef]

27. Nilzén, V.; Babol, J.; Dutta, P.C.; Lundeheim, N.; Enfält, A.-C.; Lundström, K. Free range rearing of pigs with access to pasture grazing-Effect on fatty acid composition and lipid oxidation products. Meat Sci. 2001, 58, 267-275. [CrossRef]

28. Hansen, L.L.; Claudi-Magnussen, C.; Jensen, S.K.; Andersen, H.J. Effect of organic pig production on performance and meat quality. Meat Sci. 2006, 74, 605-615. [CrossRef] [PubMed]

29. Helge, J.V.; Ayre, K.J.; Hulbert, A.J.; Kiens, B.; Storlien, L.H. Regular exercise modulates muscle membrane phospholipid profile in rats. J. Nutr. 1999, 129, 1636-1642. [CrossRef] 
30. Quiles, J.L.; Huertas, J.R.; Ochoa, J.J.; Battino, M.; Mataix, J. Dietary fat (virgin olive oil or sunflower oil) and physical training interactions on blood lipids in the rat. Nutrition 2003, 19, 363-368. [CrossRef]

31. Daza, A.; Rey, A.I.; Olivares, A.; Cordero, G.; Toldrá, F.; López-Bote, C.J. Physical activity-induced alterations on tissue lipid composition and lipid metabolism in fattening pigs. Meat Sci. 2009, 81, 641-646. [CrossRef] [PubMed]

32. Montel, M.C.; Masson, F.; Talon, R. Bacterial Role in Flavour Development. Meat Sci. 1998, 49 (Suppl. 1), S111-S123. [CrossRef]

33. Zanardi, E.; Ghidini, S.; Battaglia, A.; Chizzolini, R. Lipolysis and lipid oxidation in fermented sausages depending on different processing conditions and different antioxidants. Meat Sci. 2004, 66, 415-423. [CrossRef]

34. Toldrá, F.; Flores, M. The role of muscle proteases and lipases in flavour development during the processing of dry-cured ham. Crit. Rev. Food Sci. Nutr. 1998, 38, 331-352. [CrossRef]

35. Turek, C.; Stintzing, F.C. Stability of essential oils: A review. Compr. Rev. Food Sci. 2013, 12, 40-53. [CrossRef]

36. Perea Sanz, L.; Montero, R.; Belloch, C.; Flores, M. Nitrate reduction in the fermentation process of salt reduced dry sausages: Impact on microbial and physicochemical parameters and aroma profile. Int. J. Food Microbiol. 2018, 282, 84-91. [CrossRef]

37. Shaikh, J.; Bhosale, R.; Singhal, R. Microencapsulation of black pepper oleoresin. Food Chem. 2006, 94, 105-110. [CrossRef]

38. Lee, S.-Y.; Kim, D.-S.; Kyung, K.H. Factors influencing the stability of garlic thiosulfinates. Food Sci. Biotechnol. 2014, 23, 1593-1600. [CrossRef]

39. Fujisawa, H.; Suma, K.; Origuchi, K.; Kumagi, H.; Seki, T.; Ariga, T. Biological and chemical stability of garlic-derived allicin. J. Agric. Food Chem. 2008, 56, 4229-4235. [CrossRef] [PubMed]

40. Lopez-Bote, C.J.; Toldrá, F.; Daza, A.; Ferrer, J.M.; Menoyo, D.; Silió, L.; Rodríguez, M.C. Effect of exercise on skeletal muscle proteolytic enzyme activity and meat characteristics in Iberian pigs. Meat Sci. 2008, 79, 71-76. [CrossRef] [PubMed]

41. Stahnke, L.H. Aroma components from dried sausages fermented with Staphylococcus xylosus. Meat Sci. 1994, 38, 39-53. [CrossRef]

42. Belitz, H.-D.; Grosch, W. Quimica de los Alimentos; Acribia: Zaragoza, Spain, 1997; 1087p.

43. Girard, J.P.; Bout, J.; Salort, D. Lipides et qualitiés des tissues adipeux et musculaires de porc, facteurs de variations. J. Recherce Porc. Fr. 1988, 20, 255-278.

44. Ruiz, J.; García, C.; Muriel, E.; Andrés, A.I.; Ventanas, J. Influence of sensory characteristics on the acceptability of dry-cured ham. Meat Sci. 2002, 61, 347-354. [CrossRef]

45. Faustman, C.; Sun, Q.; Mancini, R.; Suman, S.P. Myoglobin and lipid oxidation interactions: Mechanistic bases and control. Meat Sci. 2010, 86, 86-94. [CrossRef]

46. Burdock, G.A. (Ed.) Fenaroli's Handbook of Flavour Ingredients, 5th ed.; CRC Press: Boca Raton, FL, USA, 2004; p. 558.

47. Garcia-Gonzalez, D.L.; Tena, N.; Aparicio-Ruiz, R.; Morales, M.T. Relationship between sensory attributes and volatile compounds qualifying dry-cured hams. Meat Sci. 2008, 80, 315-325. [CrossRef]

48. Flores, M.; Grimm, C.C.; Toldra, F.; Spanier, A.M. Correlations of sensory and volatile compounds of Spanish "Serrano" dry-cured ham as a function of two processing times. J. Agric. Food Chem. 1997, 45, 2178-2186. [CrossRef]

49. Zhao, J.; Wang, M.; Xie, J.; Zhao, M.; Hou, L.; Liang, J.; Wang, S.; Cheng, J. Volatile flavour constituents in the pork broth of black-pig. Food Chem. 2017, 226, 51-60. [CrossRef] [PubMed]

50. Corral, S.; Salvador, A.; Flores, M. Salt reduction in slow fermented sausages affect the generation of aroma active compounds. Meat Sci. 2013, 93, 776-785. [CrossRef] [PubMed]

(C) 2019 by the authors. Licensee MDPI, Basel, Switzerland. This article is an open access article distributed under the terms and conditions of the Creative Commons Attribution (CC BY) license (http:// creativecommons.org/licenses/by/4.0/). 